\title{
Vital Sign Monitor Device Equipped with a Telegram Notifications Based on Internet of Thing Platform
}

\author{
Sari Luthfiyah ${ }^{1}$, Agatha Putri Juniar $\mathrm{S}^{1}$, , Tri Bowo Indrato ${ }^{1}$, Michelle Omoogun ${ }^{2}$ \\ ${ }^{1}$ Department of Electromedical Engineering Poltekkes Kemenkes, Surabaya \\ Jl. Pucang Jajar Timur No. 10, Surabaya, 60245, Indonesia \\ ${ }^{2}$ Middlesex University (Mauritius Campus Branch), Vacoas, Mauritius
}

\begin{tabular}{l}
\multicolumn{1}{c}{ Article Info } \\
\hline Article History: \\
Received July 19, 2021 \\
Revised August 14, 2021 \\
Accepted August 20, 2021
\end{tabular}

Keywords:

Vital Sign Monitor

Piezoelectric

DS18B20

Respiration Rate

Temperature

\begin{abstract}
Vital Sign Monitor is a tool used to diagnose a patient who needs intensive care to know the condition of the patient. Parameters used in monitoring the patient's condition include body temperature and respiration. The contribution of this research designed a vital sign monitoring tool with IoT-based notifications so that remote monitoring can be done by utilizing web Thinger.io, LCD, RGB LEDs as a display of the results of the study and notify telegrams if it becomes abnormal to the patient's condition. Therefore, in order to produce accurate data in the process of data retrieval, a relaxed position of the patient is required and the stability of the wi-fi network so that monitoring is not hampered. The study used the DS18B20 digital temperature sensor placed on the axilla and the piezoelectric sensor placed on the abdomen of the patient. The results of the study were obtained by taking data on patients. The resulting temperature value will be compared to the thermometer, which produces the highest error value of $0.56 \%$, which is still possible because the tolerance limit is $10 \mathrm{C}$. and for the collection of respiration values that have been compared to the patient monitor obtained the highest error value of $6.2 \%$, which is still feasible because the tolerance limit is $10 \%$. In this study, there is often a crash library between the temperature sensor and other sensors, so for further research, recommend to replacing the temperature sensor.
\end{abstract}

\author{
Corresponding Author: \\ Sari Luthfiyah \\ Corresponding Email: sariluth@poltekkesdepkes-sby.ac.id \\ Department of Electromedical Engineering \\ Poltekkes Kemenkes, Surabaya
}

This work is an open-access article and licensed under a Creative Commons Attribution-ShareAlike 4.0 International License (CC BY-SA 4.0).

\section{INTRODUCTION}

Monitoring of vital signs is a measurement of a person's health condition[1][2][3]. Monitoring is necessary in case of symptoms of a disease that must be taken quickly so that the patient's condition does not worsen[4][5][6]. The patient's condition can deteriorate anywhere and anytime. Therefore, a tool equipped with a system that can notify the doctor to perform actions If the patient shows less or more results than normal[7][8][9].

In this study, the monitoring of vital signs was created to monitor heart rate, body temperature, oxygen saturation, and respiration. Previous research has been done by Anggi Zafia made a Prototype vital Monitoring Tool Sign Inpatients using Wireless Sensors as a Physical Distancing Effort to deal with Covid 19 using Zigbee[10][11][12]. For respiratory frequency gauges have also been made in 2018 by Ni Putu Anggi Trisna D about Design And Build Vital Signs Examination Tool Appear PC ( Respiration \&Heart Rate), using sensor FC-04, but the use of this sensor will make the patient uncomfortable because when measuring respiration that must use the mouthpiece so that it will affect the breath[13][14][15]. In addition, respiratory rate measuring instruments have also been made in 2015 by Wendi Era Sonata and Wildian with Design And Build MicrocontrollerBased Human Breathing Rate Measurement Tool Atmega8535[16][17][18], at Andalas University Department of Physics FMIPA using LM35 temperature sensor, the tool has an accuracy of $96.5 \%$ for measurement of patients with mild activity. Another research in 2019 by Demtania Gusti Kristiani has been made the measuring of vital signs using the internet of things Technology[19][20][21]; it uses a flex sensor that has an error value of $2.3 \%$. Meanwhile, if reviewed from the use of other sensors such as piezoelectric sensors that have been made by Hazhiyah Nur Amalina in 2019 about monitoring respiratory rate and spo 2 via android (respiratory parameter rate), in this study, it is recommended to use piezoelectric sensors because it is more sensitive to the stomach and chest movement to detect breathing rate[22][23][24].

The purpose of this study is to design a Vital Sign Monitoring Tool with IoT-Based Notification (Respiration 


\section{Indonesian Journal of Electronics, Electromedical Engineering, and Medical Informatics (IJEEEMI) \\ IJEEMI, Vol. 3, No. 3, August 2021, pp. 108-113}

DOI: 10.35882/ijeeemi.v3i3.4

Parameters and Body Temperature). This monitoring can be used to diagnose patient health anywhere and anytime and so that the patient or user can monitor his vital condition displayed through the status on display, the application thinger.io, forwarded delivery to telegram if the patient's condition is not normal[25]. Patients with late adolescence can use this study to connect well with medical experts and receive timely treatment.

\section{MATERIALS AND METHODS}

\section{A. Experimental Setup}

This study used six normal subjects with the criteria the ages ranged between 22 and 27 years. The subjects were randomly sampled, and the data collection is repeated six times.

\section{1) Materials and Tool}

This study used piezoelectric as respiration sensor and DS18B20(DS18B20, Dallas, China) as a body temperature sensor, character LCD, RGB LED Arduino Mega 2560 microcontroller, and ESP32 used for serial communication. Oscilloscopes(Textronic, DPO2012, Taiwan) are used to test analog circuits.

\section{2) Experiment}

In this study, after the design was completed, DS18B20 (DS18B20, Dallas, China) sensor testing was conducted using thermometers and piezoelectric sensor testing using patient monitors (Mindray, Beneheart D6, China).

\section{B. The Diagram Block}

In this research, Body temperature is detected by the DS18B20 sensor and the respiration rate using piezoelectric sensors. The results of the sensor readings will enter the Arduino Mega 2560 microcontroller as a data processor, which will then be sent serially to the ESP32. Furthermore, the wi-fi on the ESP32 will send data to the thinger.io server. If the data output from the parameters is not normal, a notification of the patient's vital status will be sent via Telegram received by the health worker, and all parameters will be displayed on the LCD, as shown in Fig. 1.

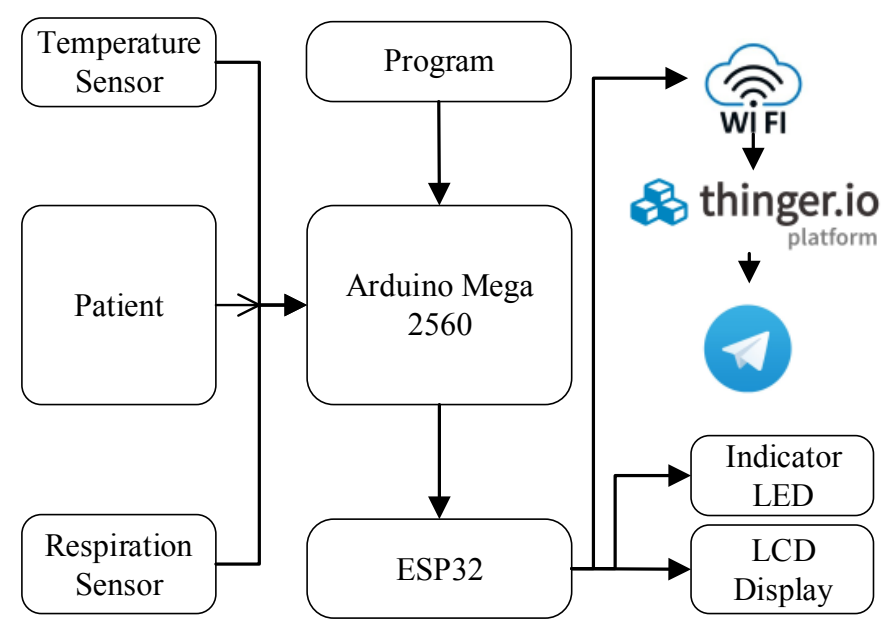

Fig. 1. The diagram block of the temperature and respiration rate

\section{The Flowchart}

The Arduino program is built based on a flowchart, as shown in Figure 2. which explains that when the on button is pressed, an initialization process occurs. The DS18B20 sensor and piezoelectric sensor will work to detect and calculate body temperature values and respiration rate values, and then these value data will be processed by the microcontroller. After the value of the two parameters has been taken, the value will be sent to the Arduino Mega microcontroller, which is communicated serially to the ESP32, which will be sent to Thinger.io, displayed on the LCD Display, and information will be sent to the Telegram accompanied by an LED indicator on the device if the patient is not in a state normal.

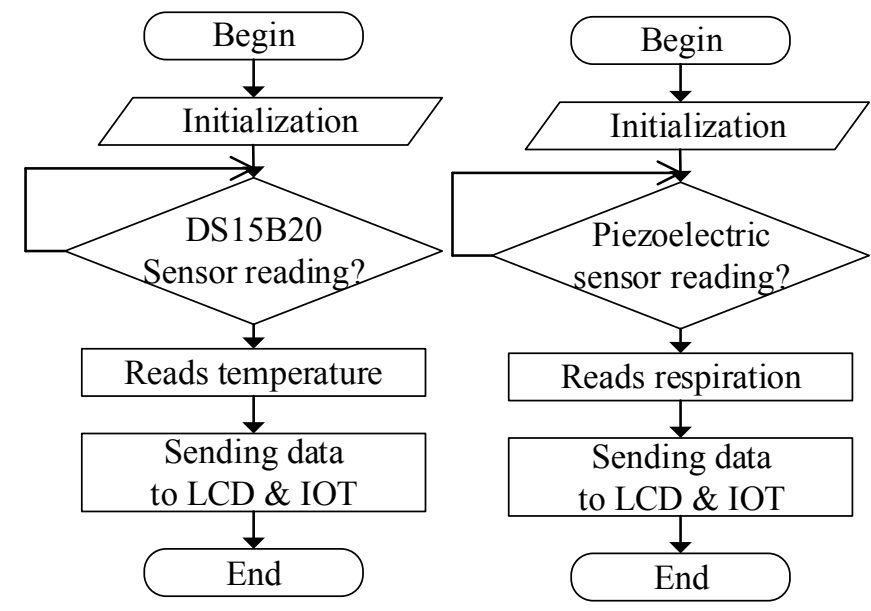

Fig. 2. The Flowchart of the temperature and respiration rate

\section{RESULTS}

In this study, the test was carried out directly on the respondent to measure the value of the respiration rate and body temperature compared to using a patient monitor(Mindray, Beneheart D6 China). and a thermometer.

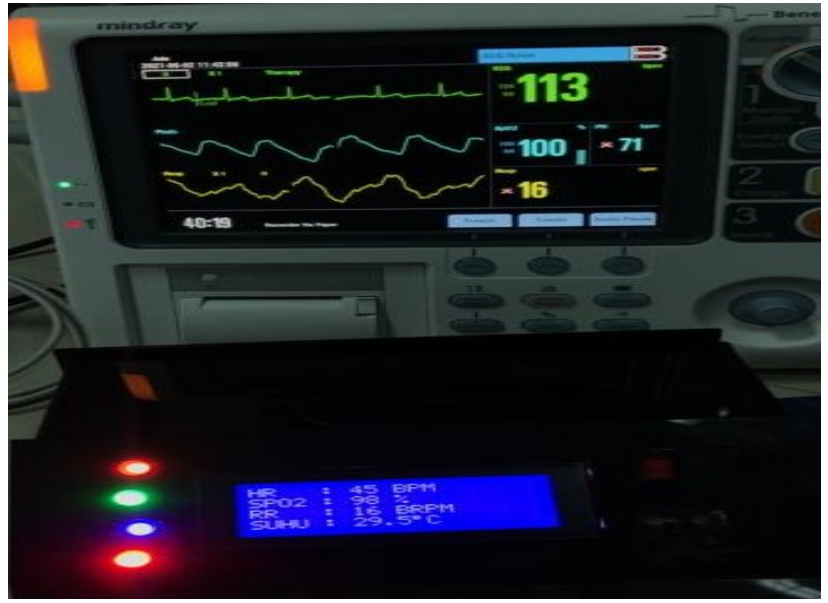

Fig. 3. The Display of Module Measurement Results with Comparison of respiratory rate values 


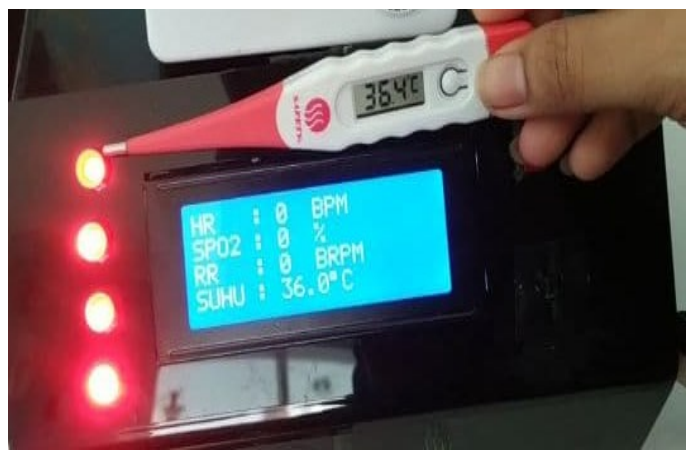

Fig. 4. The Display of Module Measurement Results with Body Temperature Value Comparison

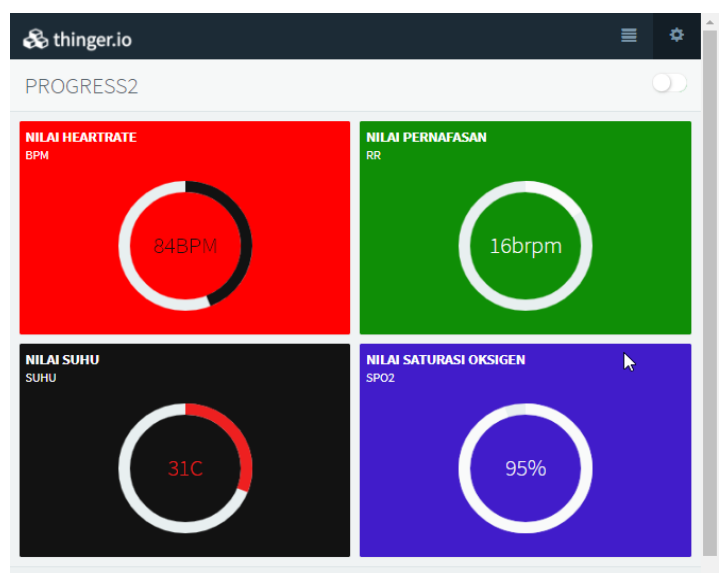

Fig. 5. Thinger.io Display

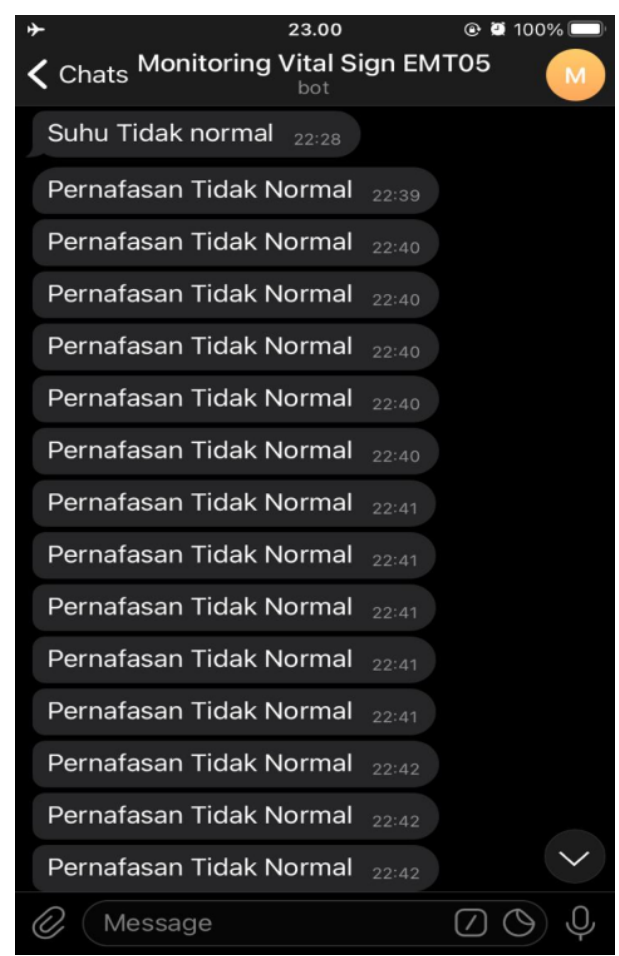

Fig. 6. Telegram Notification Display

\section{1) Vital Sign Tool Results}

Figure 3 and Figure 4 above are the measurement results of the module with comparison. RGB LED as an indicator when there is an abnormality in the measurement of body temperature and respiration rate, the abnormality will be indicated by RGB LED color, if the parameter value below the average RGB LED will be red when normal will be green, and when above-average it will be blue.

Figure 5 is a view of the respiration rate and body temperature values that can be seen when the tool is connected to the Thingerio. It can be viewed on the dashboard section of the thinger.io.

Figure 6 is a notification display of the respiration rate and body temperature value on Telegram. Telegram will give a notification if the respiration rate and body temperature values are abnormal.

2) Listing Program Arduino Mega 2560 Serial Communication

In this paper, The use of serial communication between Arduino Mega 2560 and ESP32 via TX RX aims to send sensor data readings to IoT Thingerio was shown in Listing Program 1.

Which consisted of the program of Arduino Mega 2560 as a sender of sensor data and as a display of data results on an LCD with an RGB LED indicator.

Listing Program 1: Program Arduino Mega 2560 as a sender of sensor data

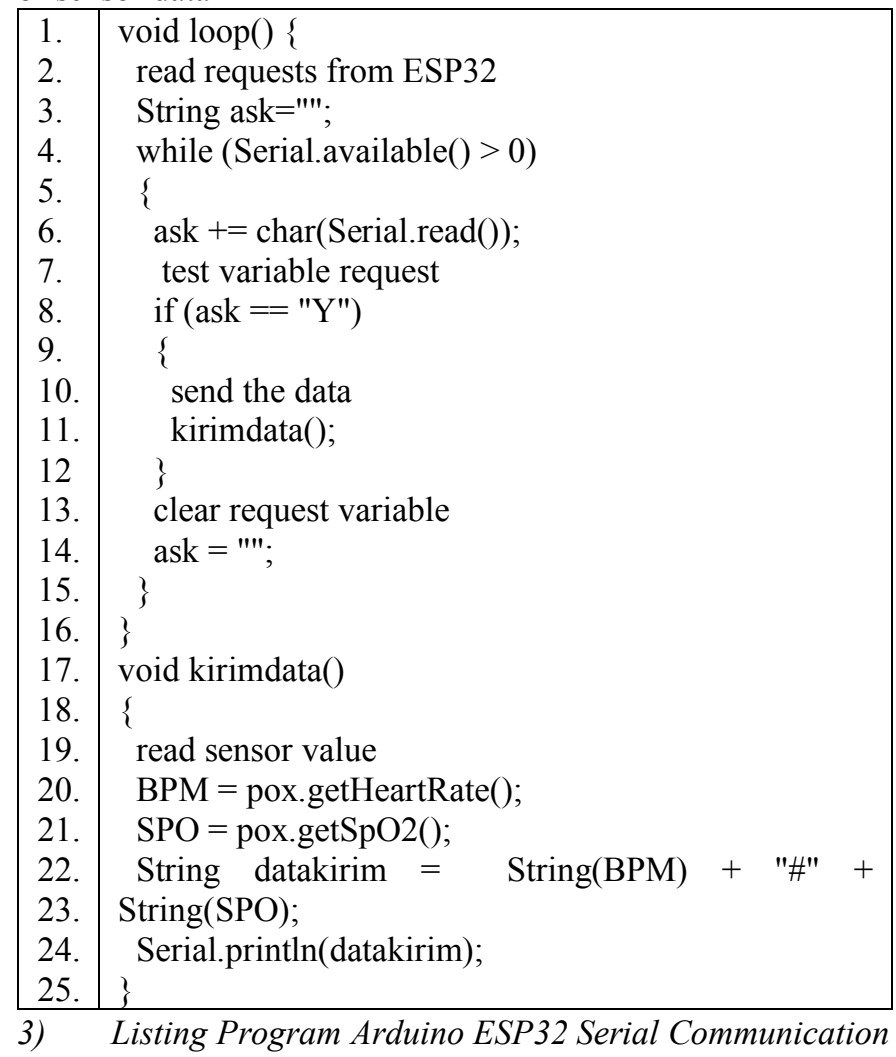


ESP32 as a receiver of sensor results whose data has been sent by Arduino Mega 2560 was shown in the Listing Program $\mathbf{2}$, and then the data is sent to IoT and telegram notification.

Listing Program 2: Program ESP32 as a received of data

\begin{tabular}{|c|c|}
\hline 1. & \#include $<$ SoftwareSerial.h $>$ \\
\hline 2. & //variable untuk software serial $(\mathrm{Rx}, \mathrm{TX})$ \\
\hline 3. & SoftwareSerial DataSerial $(16,17)$; \\
\hline $\begin{array}{l}4 . \\
5\end{array}$ & //millis sebagai pengganti delay \\
\hline 6. & unsigned long previousMillis =0; \\
\hline 7. & const long interval $=3000$ \\
\hline 8. & \\
\hline 9. & //variable array untuk data parsing \\
\hline 10. & String arrData[4]; //sesuai jumlah sensor \\
\hline 11. & int BPM,SPO; \\
\hline 12 & \\
\hline 13. & void $\operatorname{setup}()\{$ \\
\hline 14. & Serial.begin $(9600)$ \\
\hline 15 . & DataSerial.begin(9600); \\
\hline 16. & \} \\
\hline 17. & \\
\hline 18. & void $\operatorname{loop}()\{$ \\
\hline 19. & //konfigurasi millis \\
\hline 20. & unsigned long currentMillis $=$ millis () ; //baca waktu \\
\hline 21. & millis saat ini \\
\hline 22. & if(currentMillis - previousMillis $>=$ interval) \\
\hline 23. & \{ \\
\hline 24. & //update previousMillis \\
\hline & previousMillis $=$ currentMillis; \\
\hline 25 . & //prioritaskan pembacaan data dari arduino uno (hasil \\
\hline 26. & kiriman data) \\
\hline 27. & //baca data serial \\
\hline & String data = "'"; \\
\hline 28. & while(DataSerial.available ()$>0)$ \\
\hline 29. & \{ \\
\hline 30. & data $+=\operatorname{char}($ DataSerial.read ()$)$ \\
\hline 31. & \} \\
\hline 32. & char buf[sizeof(data)]; \\
\hline 33. & data.trim(); \\
\hline 34. & data.toCharArray(buf,sizeof(buf)); \\
\hline 35. & char $* \mathrm{p}=\mathrm{buf}$ \\
\hline 36. & while $(($ str=strtok_r(p,"\#",\&p))!=NULL $)\{$ \\
\hline 37. & //Serial.println(str); \\
\hline 38. & $\operatorname{arrData}[$ indexnya $]=$ str; \\
\hline 39. & indexnya ++ ; \\
\hline 40. & //Serial.println("index ke: "+String(indexnya)+" \\
\hline 41. & datanya: "+str); \\
\hline 42. & \} \\
\hline 43. & if(indexnya $>2$ ) \\
\hline 44. & \{ \\
\hline 45. & //tampilkan nilai sensor ke serial monitor \\
\hline 46. & Serial.println("HeartRate : " + arrData[0]);//BPM \\
\hline 47. & Serial.println("Saturasi O2 : " + arrData[1]);//SPO \\
\hline
\end{tabular}

\begin{tabular}{|l|ll|}
\hline 48. & Y \\
49. & //minta data ke arduino Mega \\
50. & DataSerial.println("Y"); \\
51. & delay(1500); \\
\hline
\end{tabular}

\section{4) Listing Program Temperature}

Initialization in the temperature program was shown in the Listing Program 3 contains the DS18B20 temperature sensor library which is a serial communication using one data line.

Listing Program 3: Program Temperature
1. \#include $<$ OneWire.h $>$
2. \#include $<$ DallasTemperature. $\mathrm{h}>$
3. \#define ONE WIRE BUS 37
4. OneWire one $\bar{W}$ ire(ONE WIRE BUS);
5. DallasTemperature sensors(\&oneWire);

\section{5) Listing Program $R R$}

Listing Program 4 explains that when the device is first turned on or reset, the module will automatically look for a reference from the incoming signal via analog pin 3. This reference serves to limit the value of the respiration signal.

Listing Program 4: Listing Program RR

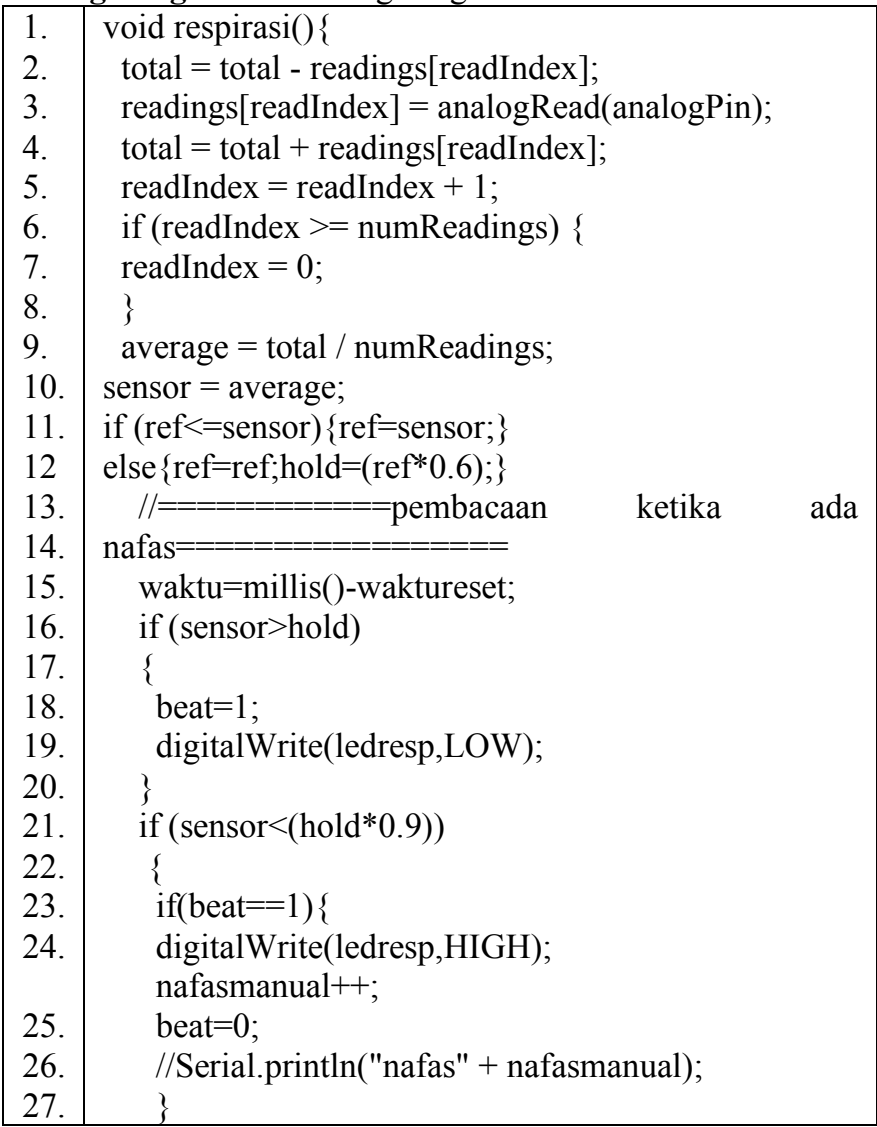

TABLE I. RESPIRATION VALUE MEASUREMENT IN MODULE COMPARED TO COMPARISON TOOL 


\section{Indonesian Journal of Electronics, Electromedical Engineering, and Medical Informatics (IJEEEMI) IJEEMI, Vol. 3, No. 3, August 2021, pp. 108-113

\begin{tabular}{|c|c|c|c|c|c|c|c|c|}
\hline \multirow{2}{*}{ Modules } & \multicolumn{6}{|c|}{ Measurement(BrPM) } & \multirow{2}{*}{ Mean } & \multirow{2}{*}{$\begin{array}{c}\text { Error } \\
(\%)\end{array}$} \\
\hline & 1 & 2 & 3 & 4 & 5 & 6 & & \\
\hline Standard & 18 & 17 & 15 & 13 & 14 & 16 & 15,5 & \multirow{2}{*}{4,3} \\
\hline Module & 16 & 16 & 13 & 13 & 15 & 16 & 14,8333 & \\
\hline Standard & 18 & 10 & 12 & 13 & 12 & 17 & 13,6667 & \multirow{2}{*}{3,7} \\
\hline Module & 17 & 10 & 13 & 11 & 11 & 17 & 13,1667 & \\
\hline Standard & 15 & 12 & 11 & 13 & 13 & 22 & 14,3333 & \multirow{2}{*}{2,3} \\
\hline Module & 12 & 12 & 13 & 12 & 14 & 21 & 14 & \\
\hline Standard & 10 & 12 & 13 & 12 & 20 & 19 & 14,3333 & \multirow{2}{*}{2,3} \\
\hline Module & 10 & 13 & 11 & 11 & 20 & 19 & 14 & \\
\hline Standard & 16 & 17 & 17 & 18 & 19 & 20 & 17,8333 & \\
\hline Module & 16 & 17 & 17 & 10 & 19 & 20 & 17,8333 & \\
\hline Standard & 16 & 19 & 12 & 17 & 15 & 18 & 16,1667 & \multirow{2}{*}{6,2} \\
\hline Module & 16 & 17 & 11 & 16 & 13 & 18 & 15,1667 & \\
\hline
\end{tabular}

study were $0.5 \%$, the result is still feasible because the tolerance limit is $1^{\circ} \mathrm{C}$. and for the measurement of respiration values that have been compared with patient monitors, the highest error value is $6.2 \%$ while the results of previous studies are $5.36 \%$, these results are still feasible because the tolerance limit is $10 \%$. In this study, there is often a crash library between the temperature sensor and other sensors, so for further research, recommend replacing the temperature sensor. Behind the lack of research, this tool has the benefit of assisting health workers in monitoring vital signs in patients remotely, and there are notifications on telegrams that can be accessed by health workers easily when abnormal conditions occur in patients.

\section{CONCLUSION}

Overall this research can be concluded that the vital sign module can monitor well and can send notifications to Telegram by using IoT. The DS18B20 sensor can detect human body temperature with a good and stable level of accuracy, and It has been possible to make a respiration monitoring device with a ceramic piezoelectric sensor that displays the results of respiratory rate measurements in the form of a number plotting graph. An IoT program can be created to display the results of respiration measurements on Thingerio. Further, the system is able to connect Arduino Mega 2560 with ESP32 Module for serial communication. The results of data collection were carried out by comparing the tool with the comparison tool six times to 6 respondents. The data taken for the temperature parameter has the lowest error value of $0.22 \%$ and the highest error value of $0.56 \%$. And for the respiration parameter, the lowest error value is $0 \%$, and the highest error value is $6.2 \%$. In this study, there is often a crash library between the temperature sensor and other sensors, so for further research, recommend replacing the temperature sensor.

\section{REFERENCES}

[1] N. V. Wardhani et al., "A Portable Vital Sign Device with Liquid Crystal Display TFT Touchscreen," Proc. - 2019 Int. Semin. Appl. Technol. Inf. Commun. Ind. 4.0 Retrosp. Prospect. Challenges, iSemantic 2019, pp. 429-433, 2019, doi: 10.1109/ISEMANTIC.2019.8884351.

[2] M. Omoogun, V. Ramsurrun, S. Guness, P. Seeam, X. Bellekens, and A. Seeam, "Critical patient eHealth monitoring system using wearable sensors," 2017 1st Int. Conf. Next Gener. Comput. Appl. NextComp 2017, no. July, pp. 169-174, 2017, doi: 10.1109/NEXTCOMP.2017.8016194.

[3] A. Singh and A. Chaudhary, "International Journal on Recent and Innovation Trends in Computing and Communication Real Time Respiration Rate Measurement Using Temperature Sensor," pp. 605-607, 2017, [Online]. Available: http://www.ijritcc.org.

[4] B. Mash, "Primary care management of the coronavirus (Covid-19)," South African Fam. Pract., vol. 62, no. 1, pp. 1-4, 2020, doi: 10.4102/safp.v62i1.5115.

[5] T. Mikami et al., "Risk Factors for Mortality in Patients with COVID-19 in New York City," J. Gen. Intern. Med., vol. 36, no. 1, pp. 17-26, 2021, doi: 10.1007/s11606-020-05983-z.

[6] W. J. Wiersinga, A. Rhodes, A. C. Cheng, S. J. Peacock, and H. C. Prescott, "Pathophysiology, Transmission, Diagnosis, and Treatment of Coronavirus Disease 2019 (COVID-19): A Review," JAMA - J. Am. Med. Assoc., vol. 324, no. 8, pp. 782-793, 2020, doi: 10.1001/jama.2020.12839.

[7] I. Prayogo et al., "Sistem Monitoring Denyut Jantung Dan Suhu Tubuh Sebagai Indikator Level Kesehatan Pasien Berbasis IoT ( Internet Of Thing ) Dengan Metode Fuzzy Logic Menggunakan Android," Program Studi Teknik Elektro, Fakultas Teknik, Universitas Trunojoyo. 2017. 
[8] G. Basaranoglu, M. Bakan, T. Umutoglu, S. U. Zengin, K. Idin, and Z. Salihoglu, "Comparison of $\mathrm{SpO} 2$ values from different fingers of the hands," Springerplus, vol. 4, no. 1, pp. 2-5, 2015, doi: 10.1186/s40064015-1360-5.

[9] J. Saha et al., "Advanced IOT based combined remote health monitoring, home automation and alarm system," 2018 IEEE 8th Annu. Comput. Commun. Work. Conf. CCWC 2018, vol. 2018-Janua, no. September, pp. 602-606, 2018, doi: 10.1109/CCWC.2018.8301659.

[10]A. Zafia, "Prototype Alat Monitoring Vital Sign Pasien Rawat Inap Menggunakan Wireless Sensor Sebagai Upaya Physical Distancing menghadapi Covid-19," J. Informatics, Inf. Syst. Softw. Eng. Appl., vol. 2, no. 2, pp. 61-68, 2020, doi: 10.20895/inista.v2i2.126.

[11]A. M. Dondorp, M. Hayat, D. Aryal, A. Beane, and M. J. Schultz, "Respiratory support in COVID-19 patients, with a focus on resourcelimited settings," Am. J. Trop. Med. Hyg., vol. 102, no. 6, pp. 1191-1197, 2020, doi: 10.4269/ajtmh.20-0283.

[12] T. Greenhalgh, G. C. H. Koh, and J. Car, "Covid-19: A remote assessment in primary care," $B M J$, vol. 368, pp. 1-5, 2020, doi: 10.1136/bmj.m1182.

[13] N. D. Putu Anggi Trisna, H. Andjar Pudji, and dan T. Moch Prastawa Assalim, "Seminar Tugas Akhir Rancang Bangun Alat Ukur Pemeriksaan Vital Signs Tampil PC ( Respirasi \& Heart Rate),” pp. 1-10, 2018.

[14]Q. Sun, H. Qiu, M. Huang, and Y. Yang, "Lower mortality of COVID-19 by early recognition and intervention: experience from Jiangsu Province," Ann. Intensive Care, vol. 10, no. 1, pp. 2-5, 2020, doi: 10.1186/s13613020-00650-2.

[15] K. G. Andersen, A. Rambaut, W. I. Lipkin, E. C. Holmes, and R. F. Garry, "The proximal origin of SARS-CoV-2," Nat. Med., vol. 26, no. 4, pp. 450 452, 2020, doi: 10.1038/s41591-020-0820-9.

[16] W. Sonata and W. -, "Rancang Bangun Alat Ukur Laju Pernapasan Manusia Berbasis Mikrokontroler Atmega8535," J. Fis. Unand, vol. 4, no. 4, pp. 332-338, 2015.

[17] M. Al-Balas, H. I. Al-Balas, and H. Al-Balas, "Surgery during the COVID19 pandemic: A comprehensive overview and perioperative care," Am. J. Surg., vol. 219, no. 6, pp. 903-906, 2020, doi: 10.1016/j.amjsurg.2020.04.018.

[18] M. A. Matthay, J. M. Aldrich, and J. E. Gotts, "Treatment for severe acute respiratory distress syndrome from COVID-19," Lancet Respir. Med., vol. 8, no. 5, pp. 433-434, 2020, doi: 10.1016/S2213-2600(20)30127-2.

[19] D. G. Kristiani, T. Triwiyanto, P. C. Nugraha, B. G. Irianto, Syaifudin, and D. Titisari, "The Measuring of Vital Signs Using Internet of Things Technology (Heart Rate and Respiration)," Proc. - 2019 Int. Semin. Appl. Technol. Inf. Commun. Ind. 4.0 Retrosp. Prospect. Challenges, iSemantic 2019, pp. 417-422, 2019, doi: 10.1109/ISEMANTIC.2019.8884312.

[20] S. N. Byrareddy and M. Mohan, "SARS-CoV2 induced respiratory distress: Can cannabinoids be added to anti-viral therapies to reduce lung inflammation?," Brain. Behav. Immun., vol. 87, pp. 120-121, 2020, doi: 10.1016/j.bbi.2020.04.079.

[21] Istikomah, “No 主観的健康感を中心とした在宅高齢者における 健康 関連指標に関する共分散構造分析Title,”2014.

[22]H. N. Amalina, I. D. Gede, H. Wisana, and T. Rahmawati, "Monitoring Respiratory Rate and Spo2 Via Android ( Parameter Respiratory Rate )," vol. 1, no. 1, pp. 1-7, 2019, doi: 10.1234/ijeeemi.v1i1.9xx.

[23]I. K. E. G. Mahardika, T. Hamzah, T. Rahmawati, and L. Soetjiatie, "Measuring Respiration Rate Based Android," Indones. J. Electron. Electromed. Eng. Med. informatics, vol. 1, no. 1, pp. 39-44, 2019, doi: 10.35882/ijeeemi.v1i1.7.

[24] Sarah Aghnia Miyagi, Muhammad Ridha Mak'ruf, Endang Dian Setioningsih, and T. Das, "Design of Respiration Rate Meter Using Flexible Sensor," J. Electron. Electromed. Eng. Med. Informatics, vol. 2, no. 1, pp. 13-18, 2020, doi: 10.35882/jeeemi.v2i1.3.

[25]A. D. Droitcour et al., "Non-contact respiratory rate measurement validation for hospitalized patients," Proc. 31st Annu. Int. Conf. IEEE Eng. Med. Biol. Soc. Eng. Futur. Biomed. EMBC 2009, pp. 4812-4815, 2009, doi: 10.1109/IEMBS.2009.5332635.

\section{[1] Schematic} https://rive.google.com/file/d/1slKW6YkkGnpo4o43Xc7Tr Qiw2OPhcPcN/view? usp=sharing

[2] Listing Program https://drive.google.com/drive/folders/1_A5q5VFPrN73QhQ jJH5uxzfV9RyEXvpZ?usp=sharing

\section{ATTACHMENT}

